\title{
Comparison of Abnormal Returns Before and After The 18th Asian Games in Indonesia (Event study of companies included in the LQ-45 Stock Index)
}

\author{
Sonja Andarini ${ }^{1}$, Rusdi Hidayat Nugroho ${ }^{2}$, Nurul Aqidatul Izzah ${ }^{3}$, Franky Nasution ${ }^{4}$ \\ \{sonja_andarini_adbis@upnjatim.ac.id ${ }^{1}$, rusdi_hidayat.adbis@upnjatim.ac.id ${ }^{2}$ \} \\ Universitas Pembangunan Nasional "Veteran" Surabaya, Indonesia ${ }^{1,2,3,4}$
}

\begin{abstract}
The Asian Games is a four-year sports competition participated by athletes from countries in Asia and competed in various types of sports. This study aims to determine and analyze differences in abnormal returns before and after the 18th Asian Games in Indonesia for companies included in the LQ-45 Stock Index. The population in this study are companies included in the LQ-45 Stock Index for the February 2018January 2019 period. The sampling technique used purposive sampling and 40 companies were used as research samples. The form of research is the event study, in which the event window consists of 5 days before and after the Asian Games in Indonesia. Hypothesis testing uses paired sample t-test. The results showed that there were differences in abnormal returns before and after the Asian Games in Indonesia, but the effect was not significant. In the period before the Asian Games in Indonesia, the highest percentage of average abnormal returns occurred in the Agriculture stock sector and the lowest in the Mining stock sector. Whereas in the period after the Asian Games in Indonesia, the highest percentage of average abnormal return occurred in the Miscellaneous Industry stock sector and the lowest in the Mining stock sector.
\end{abstract}

Keywords: Event Study, Abnormal Return, Asian Games, LQ-45 Stock Index.

\section{Introduction}

In the midst of increasingly high competition in the financial markets, the Indonesian capital market continues to grow and develop significantly over time. This can be seen from the increasing number of securities registered and traded on the capital market with a fairly large market capitalization. Hadi [1] argues that the capital market is a means or meeting place for sellers and buyers. Sellers and buyers in this case are sellers and buyers of financial instruments for investment. Capital market (capital market) is a market for a variety of longterm financial instruments that can be traded, both bonds, equities (stocks), mutual funds, derivative instruments and other instruments (Indonesia Stock Exchange, 2018).

This research uses event study research to study and analyze the reaction of investors in the capital market to an event. Event studies are studies that study market reactions to an event whose information is published as an announcement and can be used to test the information content of the announcement [2].

In investing in the capital market, investors need information disclosure related to the company's internal conditions, such as the company's fundamentals and or financial as well as other external conditions that can affect the movement of a company's stock prices. These 
things will encourage investor reaction in the capital market related to investor's decision to invest.

Investor's reaction or response to the event is measured using abnormal return. Abnormal return or excess return shows the excess of returns that actually occur against normal returns [3]. Abnormal return is used as an indicator to see capital market reactions to certain information, which means that every market reaction is indicated in the abnormal return there is information content in it [4]. When using abnormal returns, it can be concluded that an event that has information content will provide an abnormal return to the market. Conversely, events that do not contain information do not provide abnormal returns to the market [5].

One of the factor that motivates investors to invest and also reward for the courage of investors to bear the risk of their investments is stock returns [6]. A new information that is entered and responded by the market can create a new market equilibrium point. Thus, investors will compete to find information that is relevant to the market. The reputation of an organisation's can affect the performance of the stock market through profitability and growth [7]. In addition, various economic, socio-cultural, political, defense and security events, the environment and human rights contain information that can create a change in the capital market.

Abnormal movements in stock prices can occur in the capital market as a whole, but can also occur in the movement of certain stocks that usually occur at certain times [8]. One noneconomic event that can create change and be responded by investors in the capital market is the event of international sports competition which is generally a positive sentiment for the economy of a country, especially the host country. The relationship between sports events and stock returns has been a topical issue in the finance literature in the past few decades [9]. One such sporting event is the Asian Games which is an international, prestigious and the biggest international sporting event in Asia.

In 2018, Indonesia was chosen to replace Vietnam to host the 18th Asian Games. The prestigious and the biggest sporting event in Asia was held on 18 August - 2 September 2018 in two main places namely Jakarta and Palembang. The existence of four annual sports events can be one of the factors that can affect the capital market. Because at the time the Asian Games were held in Indonesia, many parties focused on Indonesia in the mass media (both print and electronic) both domestically and abroad, including investors all over the world. Interesting things about Indonesia can encourage investors to invest and can also have an impact on the condition of the capital market in Indonesia.

According to the data sourced from the Minister for National Development Planning (PPN/Bappenas), the direct economic impact of the Asian Games is estimated to reach IDR 40.6 trillion from 2015-2018. The most impact was for construction investment of Rp29.1 trillion. The economic impact stemming from the operations of the Asian Games is estimated to reach Rp7.8 trillion. Meanwhile, the economic impact stemming from tourist spending, both foreign and local, reached Rp3.7 trillion. In detail, the expenditure of foreign tourists (tourists) is estimated to reach Rp1,9 trillion. Meanwhile, domestic tourists (wisnus) spent spending during the Asian Games reaching Rp1.8 trillion [10].

Tests will be conducted on companies included in the LQ-45 Stock Index for the period February 2018 - January 2019. The selection of the LQ-45 Stock Index as a research object because the Index is selected stocks that have high liquidity, large market capitalization and pass the selection according to several selection criteria [6]. Every six months the list of shares in the LQ-45 Stock Index is updated, namely in February and August.

This study aims to determine and analyze the presence or absence of differences in abnormal return of shares in companies included in the LQ-45 Stock Index before and after the 
18th Asian Games sporting events in Indonesia. Thus, the hypothesis in this study is that it is suspected that there are differences in abnormal returns in companies included in the LQ-45 Stock Index before and after the 18th Asian Games in Indonesia.

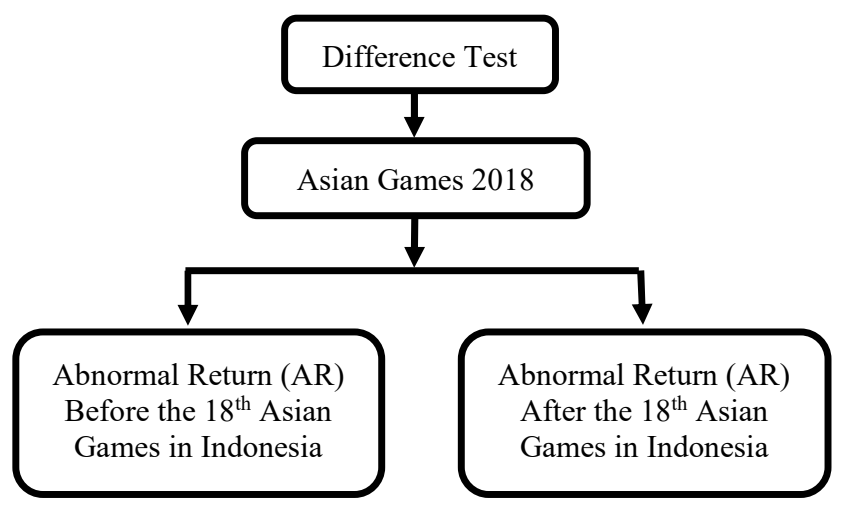

Fig. 1. Framework of Thinking.

\section{Research Methodology}

This type of research is research with a quantitative approach to the form of event study research (event studies). In this study, the data source used is secondary data obtained from Yahoo Finance (finance.yahoo.com), the Indonesia Stock Exchange which is published on the official website of the Indonesia Stock Exchange (www.idx.co.id), and other relevant publications with this research. The variables used in this study are as follows:

\subsection{Abnormal Return (X)}

Abnormal Return is the difference between actual return and expected return. The order of abnormal return calculation is determining the actual return, the market return, the abnormal return, then the average abnormal return.

a) Calculating Actual Return

$$
R_{i, t}=\frac{P_{i, t}-P_{i, t-1}}{P_{i, t-1}}
$$

$\begin{array}{lll}\text { Information: } & \\ \mathrm{R}_{\mathrm{i}, \mathrm{t}} & = & \text { issuer's actual return } \mathrm{i} \text { on day } \mathrm{t} \\ \mathrm{P}_{\mathrm{i}, \mathrm{t}} & = & \text { issuer's stock price } \mathrm{i} \text { on day } \mathrm{t} \\ \mathrm{P}_{\mathrm{i}, \mathrm{t}-1} & = & \text { issuer's stock price } \mathrm{i} \text { at time } \mathrm{t}-1\end{array}$

b) Calculating Market Return (Rm)

This study uses LQ-45 data, so the market index used is the LQ-45 Stock Index with the following formula: 


$$
R_{m}=\frac{L Q 45 \text { Index }_{t}-L Q 45 \text { Index }_{t-1}}{\text { LQ45 Index }_{t-1}}
$$

Information:

\begin{tabular}{|c|c|}
\hline $\begin{array}{l}\mathrm{R}_{\mathrm{m}} \\
\mathrm{L} 045 \text { Index. }\end{array}$ & $\begin{array}{l}=\text { market return when } \mathrm{t} \\
=\mathrm{LO} 45 \mathrm{Index} \text { at time } \mathrm{t}\end{array}$ \\
\hline $\begin{array}{l}\text { LQ45 Index } \\
\text { LQ45 Index } \\
\text { L-1 }\end{array}$ & $\begin{array}{l}=\mathrm{LQ} 45 \text { Index at time } \mathrm{t} \\
=\mathrm{LQ} 45 \text { index at time } \mathrm{t}-1\end{array}$ \\
\hline
\end{tabular}

c) Calculating Abnormal Return (AR)

Abnormal return is the difference between actual return and expected return. Calculation of expected return in this study uses the market adjusted model method so that the expected return is the same as the market return. The abnormal return formula is as follows:

$$
A R_{i, t}=R_{i, t}-R_{m}
$$

Information:

$$
\begin{array}{ll}
\mathrm{AR}_{\mathrm{i}, \mathrm{t}} & =\text { abnormal stock return } \mathrm{i} \text { on day } \mathrm{t} \\
\mathrm{R}_{\mathrm{i}, \mathrm{t}} & =\text { actual stock return } \mathrm{i} \text { on day } \mathrm{t} \\
\mathrm{R}_{\mathrm{m}} & =\text { stock market return } \mathrm{i} \text { on day } \mathrm{t}
\end{array}
$$

d) Calculating Average Abnormal Return (AAR)

$$
A A R_{i, t}=\sum_{t=1}^{n} \frac{A R_{i, t}}{n}
$$

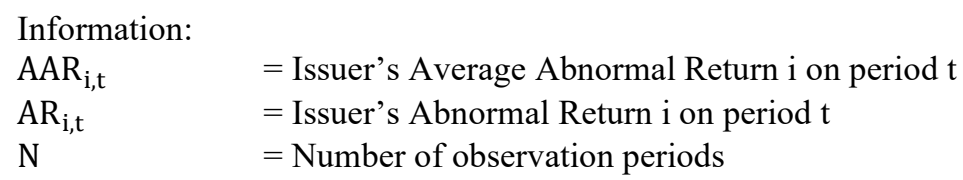

\subsection{Asian Games 2018 (Y)}

The basis for the selection of the $18^{\text {th }}$ Asian Games sporting events in Indonesia is because the event is an international, prestigious and the largest scale sporting event at the Asian level and has become a wide spotlight in the mass media, both print and electronic from domestic and abroad.

The population used in this study are company shares listed on the Indonesia Stock Exchange and included in the LQ-45 Stock Index. Sampling of research using non-probability sampling method with purposive sampling technique. Table 1 for determining criteria for research sampling.

The observation period used in this study was 1 exchange day and 10 days were observed, namely 5 (five) days before the event (t-5) and 5 (five) days after the event occurred $(t+5)$. Data collection methods in this study use the method of documentation and literature collected from various sources and references.

To prove the analysis that states that abnormal returns before and after the 18th Asian Games in Indonesia have differences, a different paired sample t-test was used. Data collected 
from the results of the study were processed and analyzed using the SPSS (Statistical Package for the Social Sciences) program with the Statistical Paired Sample T-Test.

Table 1. Determination of Withdraw of Research Samples

\begin{tabular}{clc}
\hline No & \multicolumn{1}{c}{ Information } & Total Company \\
\hline 1 & $\begin{array}{l}\text { Companies included in the LQ-45 Index shares during the period } \\
\text { estimation and window period }\end{array}$ & 45 \\
\hline 2 & $\begin{array}{l}\text { Companies that are not in a manner consistently entered in the } \\
\text { LQ-45 Stock Index during the estimated period and window } \\
\text { period }\end{array}$ & (5) \\
\hline & Total Samples & 40 \\
\hline & (Data processed, 2019)
\end{tabular}

\section{Result and Discussion}

The object of research used was companies included in the LQ-45 Stock Index for the February 2018 - January 2019 period, which companies consistently entered in the LQ-45 Stock Index during the observation period. 45 companies are included in the LQ-45 Stock Index. However, there were 40 companies that were consistently included in the LQ-45 Stock Index during the observation period as a research sample.

The Percentage of Average Abnormal Return obtained by the company before and after the 18th Asian Games in Indonesia which are grouped into several sectors included in the LQ45 Index can be seen in the diagram.

Diagram 1. Percentage of Average Abnormal Return Before the $18^{\text {th }}$ Asian Games in Indonesia

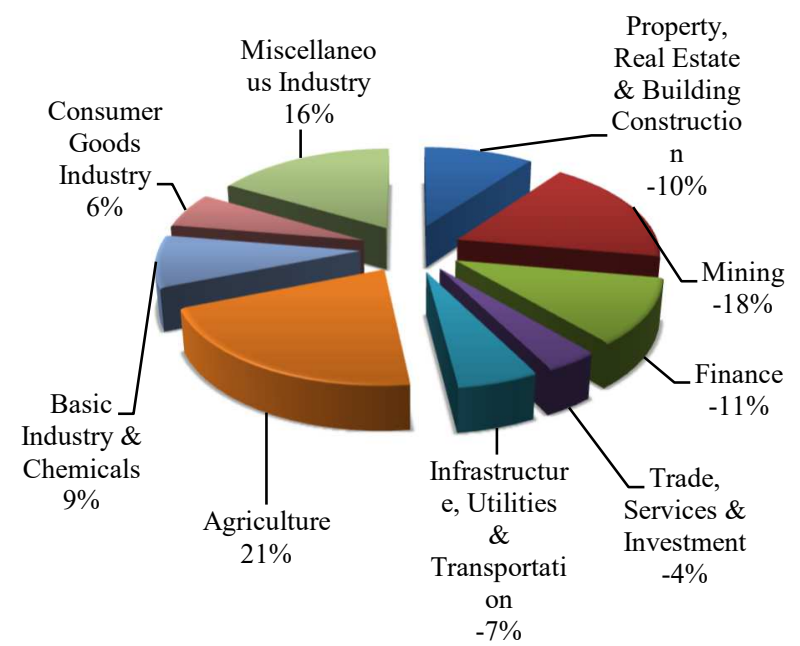

Source: Secondary data processed, 2019.

Based on diagram 1 regarding the percentage of Average Abnormal Return obtained by each sector of shares included in the LQ-45 Stock Index in the period before the $18^{\text {th }}$ Asian 
Games in Indonesia, it can be seen that the highest percentage of average abnormal return occurred in the Agriculture stock sector by $21 \%$ and the lowest percentage value of average abnormal return in the Mining stock sector that is equal to $-18 \%$.

Diagram 2. Percentage of Average Abnormal Return After the $18^{\text {th }}$ Asian Games in Indonesia

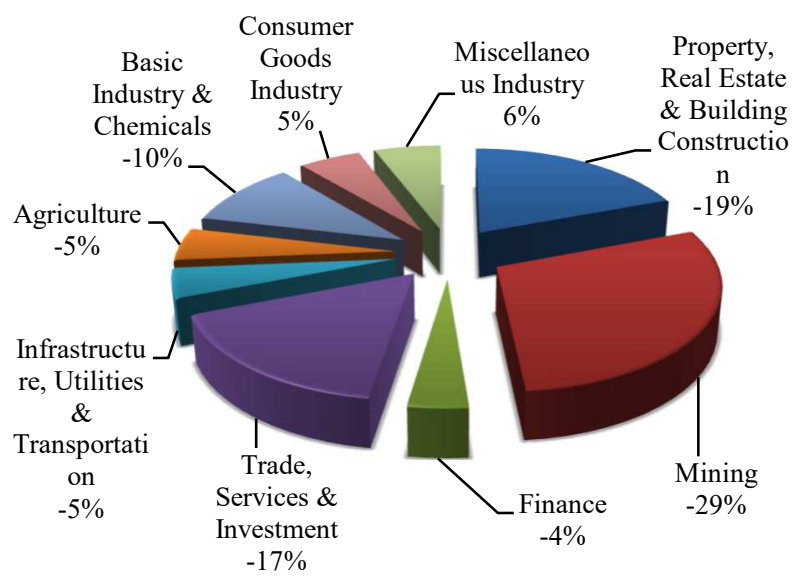

Source: Secondary data processed, 2019.

Diagram 2 it can be seen that the percentage value of average abnormal returns in the period after the 18th Asian Games in Indonesia tends to decrease, except for the Finance stock sector which has increased by a percentage value of $-4 \%$. While the lowest percentage value of average abnormal return occurred in the Mining stock sector that is equal to $-29 \%$ and the highest percentage value of average abnormal return is $6 \%$ originating from Miscellaneous Industry stock sectors.

\subsection{Research results}

In this section, the results and discussion of the capital market reaction to the 18th Asian Games in Indonesia will be measured using abnormal returns. The results of testing the hypothesis in this study are as follows table 2 .

Table 2. Paired Sample T-Test Abnormal Return Test

\begin{tabular}{|c|c|c|c|c|c|c|c|c|}
\hline \multicolumn{9}{|c|}{ Paired Samples Test } \\
\hline & \multicolumn{5}{|c|}{ Paired Differences } & \multirow{3}{*}{$\mathrm{t}$} & \multirow{3}{*}{ df } & \multirow{3}{*}{$\begin{array}{l}\text { Sig. (2- } \\
\text { tailed) }\end{array}$} \\
\hline & \multirow[t]{2}{*}{ Mean } & \multirow{2}{*}{$\begin{array}{c}\text { Std. } \\
\text { Deviation }\end{array}$} & \multirow{2}{*}{$\begin{array}{l}\text { Std. Error } \\
\text { Mean }\end{array}$} & \multicolumn{2}{|c|}{$\begin{array}{l}95 \% \text { Confidence Interval of } \\
\text { the Difference }\end{array}$} & & & \\
\hline & & & & Lower & Upper & & & \\
\hline \begin{tabular}{c|l} 
& AR_Pre_ \\
Pair & Event- \\
1 & AR_Post_ \\
& Event
\end{tabular} &, 0037660 & ,0302794 &, 00214411 &,- 0004562 & ,0079881 & 1,759 & 199 &, 080 \\
\hline
\end{tabular}

Source: Data processed using SPSS, 2019. 


\subsection{Research Discussion}

Based on data analysis using paired sample t-test shows that there is a difference between abnormal return before the $18^{\text {th }}$ Asian Games event in Indonesia and abnormal return after the $18^{\text {th }}$ Asian Games event in Indonesia, but the effect is not significant. This is because the capital market reacts to the $18^{\text {th }}$ Asian Games in Indonesia, but investor's expectations of stock prices at the time of the Asian Games have no significant effect, because it is a positive sentiment for the capital market and not a negative sentiment to worry about.

The difference in value on the 5 (five) days before the $18^{\text {th }}$ Asian Games in Indonesia and after the $18^{\text {th }}$ Asian Games in Indonesia does not have a significant effect indicating that changes in stock returns owned by companies around the event are normal price changes.

\section{Conclusions}

a) There are differences in Abnormal Returns before and after the $18^{\text {th }}$ Asian Games in Indonesia, but the effect is not significant. This is because the capital market reacts to the event, but investor's expectations of stock prices at the time of the Asian Games have no significant effect, because it is a positive sentiment for the capital market. This event shows that the holding of the Asian Games is not one of the valuable information for investors in making investment decisions.

b) The highest percentage value of Average Abnormal Return in the period before the $18^{\text {th }}$ Asian Games in Indonesia occurred in the Agriculture stock sector by $21 \%$ and the lowest is $-18 \%$ occurred in the Mining stock sector. While the lowest percentage of the average abnormal return period after the $18^{\text {th }}$ Asian Games in Indonesia occurred in the Mining stock sector that is $-29 \%$ and the highest average abnormal return rate of $6 \%$ originating from the Miscellaneous Industry stock sector.

\subsection{Suggestions}

a) Future researchers who will conduct research with the same theme should take more variables with a longer observation period. That way, there will be an increase in the quality and accuracy of research results.

b) The Asian Games sport event is one of the moments for investors to invest, one of them is in the form of shares, because it is a positive sentiment for the capital market. However, investors should not make this phenomenon the only consideration or main guideline for investment decisions, so that investors can make more informed decisions regarding their investments.

\section{References}

[1] N. Hadi, "Pasar Modal (Kedua ed.)," Yogyakarta Graha Ilmu, 2015.

[2] N. Mukuan, S. Murni, and H. H. D. Tasik, "Reaksi Investor Di Pasar Modal Indonesia Terhadap Pengumuman Pencalonan Presiden Joko Widodo (Studi Kasus Pada Saham LQ45)," J. EMBA, vol. 7, no. 1, pp. 1201-1210, 2019.

[3] F. Purba and S. R. Handayani, "Analisis Perbedaan Reaksi Pasar Modal Indonesia Sebelum dan 
Sesudah Peristiwa Non Ekonomi (Studi pada Peristiwa Politik Pilkada DKI Jakarta 2017 Putaran Kedua)," J. Adm. Bisnis, vol. 51, no. 1, pp. 115-123, 2017.

[4] D. Danusatrio and S. Sulasmiyati, "Analisis Reaksi Pasar Modal Sebelum Dan Setelah Penutupan Program Tax Amnesty (Studi pada Saham Perusahaan Sektor Keuangan yang Terdaftar di Bursa Efek Indonesia (BEI) dan Ditunjuk sebagai Gateway dalam Pelaksanaan Program Tax Amnesty)," J. Adm. Bisnis, vol. 60, no. 2, pp. 153-161, 2018.

[5] J. Hartono, Teori Portofolio dan Analisis Investasi. Yogyakarta: BPFE - UGM, 2015.

[6] E. Tandelilin, "Portofolio dan Investasi, Edisi Pertama," Yogyakarta: Kanisius, vol. 1, no. 1, 2010.

[7] H. N. Rusdi, B. W. Otok, and K. Roy, "Moderating entrepreneurship at corporate reputation in business performance using partial least square," Int. J. Mech. Eng. Technol., vol. 9, no. 9, pp. 348-358, 2018.

[8] R. Pratiwi and M. Yusuf, "Reaksi Pasar Dalam Bentuk Return Sebelum, Selama, dan Sesudah Peristiwa Piala Dunia Tahun 2014 pada Pasar Modal Asean," JRAP (Jurnal Ris. Akunt. dan ..., 2015.

[9] A. E. Osuala, G. U. Nwansi, and J. I. Osuji, "Comparative Analysis of the Impact of International Soccer Wins on the Stock Market: Evidence from Nigeria."

[10] Katadata.co.id, "Bappenas Hitung Asian Games Sumbang Pertumbuhan Ekonomi 005," October 16, 2018. [Online]. Available: https://katadata.co.id/berita/2018/10/16/bappenas-hitung-asiangames-sumbang-pertumbuhan-ekonomi-005. [Accessed: 07-Apr-2019]. 